\title{
Single strand confirmation polymorphism (SSCP) detection in exon I of the $\alpha$-lactalbumin gene of Indian Jamunapari milk goats (Capra hircus)
}

\author{
Dinesh Kumar, Neelam Gupta, S.P.S. Ahlawat, R. Satyanarayana, Shyam Sunder and S.C. Gupta \\ National Bureau of Animal Genetic Resources, Karnal, India
}

\begin{abstract}
The genetic diversity of Jamunapari goats (Capra hircus) was investigated using an optimized non-radioactive polymerase chain reaction single-strand conformation polymorphism (PCR-SSCP) method to detect $\alpha$-lactalbumin polymorphism in a sample of 50 goats. Our data show that PCR-SSCP is an appropriate tool for evaluating genetic variability in Jamunapari goats. Polymorphism was detected in the sample, indicating that Jamunapari goats have high genetic variability at loci, exon I of the $\alpha$-lactalbumin gene. This result opens interesting prospects for future selection programs and conservation strategies. These $\alpha$-lactalbumin variants can be sequenced and screened in the population to develop single nucleotide polymorphism (SNP) markers for association studies and marker assisted selection.
\end{abstract}

Key words: alpha-lactalbumin, genetic variability, goat, single-strand conformation polymorphism (SSCP).

Received: May 10, 2005; Accepted: August 26, 2005.

India has 20 well-defined breeds of goats (Capra hircus), representing a wide spectrum of genetic variability. Within each Indian goat breed the variation in phenotypes and production levels is primarily because of extensive management under low input, with little selection being practiced by the farmers (Ahlawat and Gupta, 2004). The genetic variability of indigenous breeds is important for conserving precious and irreplaceable genetic resources which may be applied to new productive demands.

The Jamunapari, Jamnapari or Etawah goat (Capra hircus) is named after an area beyond the river Jamuna where the breed was developed and is a dual purpose milk-and-meat goat breed which is mainly found in the undulated land of Chakarnagar between the ravines of the Jamuna (Yamuna) and Chambal rivers in the Etawah district of the Indian state of Uttar Pradesh (Acharya, 1982). The predominantly white-haired Jamunapari goat is probably the tallest and most handsome of Indian goat breeds (Singh, 1966), the other distinguishing feature of the breed being a thick growth of long hair on the hindquarters. They have a large body, long and wide pendulous ears, a pronounced Roman nose and parrot mouth, and short and flat horns. The breed is a prolific and non-seasonal breeder (Devendra, 1985) and females possess large udders with big teats and are well known for milk production because

Send correspondence to Dinesh Kumar. National Bureau of Animal Genetic Resources, Small Ruminant Molecular Genetics Lab DNA Fingerprinting Unit, Karnal 132001 Haryana, India. E-mail: dineshbhu@rediffmail.com. they produce the highest amounts of milk of all Indian goat breeds, milk yield ranging from 1.13 to $3.63 \mathrm{~kg} \mathrm{~d}^{-1}$ or about $200 \mathrm{~kg}$ per lactation (Acharya, 1982, Rout et al., 2004) and growth (Singh, 1966). Variation in milk yield has been reported to be associated with management differences as well as variability in genetic makeup of the goats (Azevedo et al., 1994). The association of genetic polymorphism with milk production and composition (Ng-Kwai-Hang, 1997) has stimulated interest in using genetic polymorphism of milk protein genes in molecular marker assisted selection (MAS) to improve milk productivity in farm animals.

The aim of this study was to evaluate the genetic variability in exon-I of the $\alpha$-lactalbumin milk gene using a non-radioactive PCR single-strand conformation polymorphism (PCR-SSCP) method in order to establish a breeding program based on molecular-assisted selection for improvement in milk yield and quality in Indian goat genetic resources.

We selected 50 genetically unrelated Jamunapari goats from the native breeding region of this breed, these goats being considered as representative of the existing gene pool of the population. Blood samples $(5-6 \mathrm{~mL})$ were obtained by jugular veinipuncture using vacuum tubes treated with $15 \%$ ethylenediaminetetraacetic acid (EDTA) as an anticoagulant. Genomic DNA was isolated as per the method described by Sambrook et al. (1989) with minor modifications. After checking the quality and quantity of the DNA it was diluted to a final concentration of $50 \mathrm{ng} \mu \mathrm{L}^{-1}$ in water and stored at $4{ }^{\circ} \mathrm{C}$. The polymerase 
chain reaction (PCR) was carried out on about 50-100 ng of genomic DNA in a $25 \mu \mathrm{L}^{-1}$ reaction volume, the goat $\alpha$-lactalbumin gene (Gene Bank M63868) exon-I primer (Vilotte et al; 1991) being used in the amplifications to produce an expected product consisting of the beginning of the exon-I region (689 to 854). The reaction mixture consisted of $200 \mu \mathrm{M}$ each of dATP, dCTP, dGTP and dTTP, $50 \mathrm{mM}$ $\mathrm{KCl}, 10 \mathrm{mM}$ Tris- $\mathrm{HCl}$ ( $\mathrm{pH} 9.0$ ), $0.1 \%$ (all percentages $\mathrm{w} / \mathrm{v}$ ) Triton X-100, $1.5 \mathrm{mM} \mathrm{MgCl} 2,0.75$ unit Taq DNA polymerase and $4 \mathrm{ng} \mu \mathrm{L}^{-1}$ of each primer (5' CTC TTG CTG GAT GTA AGG CTT3'; 5' AGC CTG GGT GGC ATG GAA TA 3') (Sigma Genosys) and two drops of mineral oil. Amplification was carried out in a PTC-200 PCR machine (M J Research Inc., MA, USA) using a hot start $\left(95^{\circ} \mathrm{C}\right.$ for $5 \mathrm{~min}$ ) and $30 \mathrm{cycles}$ of $30 \mathrm{~s}$ at $95^{\circ} \mathrm{C}, 62^{\circ} \mathrm{C}$ and $72^{\circ} \mathrm{C}$ consecutively, followed by a five min final extension at $72{ }^{\circ} \mathrm{C}$. Amplification was verified by electrophoresis of the PCR products with loading dye ( $95 \%$ formamide, $0.25 \%$ bromophenol blue and $0.25 \%$ xylene cyanol) on $2 \%$ $(\mathrm{w} / \mathrm{v})$ agarose gel in $1 \mathrm{x}$ TAE buffer using a $10 \mathrm{bp}$ ladder as marker for confirmation of the length of the PCR products. Gels were stained with ethidium bromide $\left(1 \mu \mathrm{m} \mathrm{L}^{-1}\right)$. The amplified products $(5 \mu \mathrm{L})$ were detected on $2 \%$ agarose gel using $1 \mu \mathrm{L}$ of loading dye as a stop dye, electrophoresed and visualized using UV light after ethidium bromide staining. The PCR products were resolved by SSCP analysis. Several factors were tested for each fragment in order to optimize factors such as the amount of PCR product, denaturing solution, acrylamide concentration, percentage cross linking, glycerol, voltage, running time and temperature. Each PCR product was diluted in denaturing solution $(95 \%$ formamide, $10 \mathrm{mM} \mathrm{NaOH}, 0.05 \%$ xylene cyanol and $0.05 \%$ Bromophenol blue, $20 \mathrm{mM}$ EDTA) denatured at $95{ }^{\circ} \mathrm{C}$ for five min, chilled on ice and resolved on polyacrylamide gel. The electrophoresis was carried out in a BioRad Protean II xi vertical electrophoreses unit using $1 \mathrm{X}$ TBE buffer. Gels were silver-stained (Sambrook and Russell, 2001) and dried on cellophane using a Biorad Model 583 gel dryer.

The SSCP analysis of exon-I of the $\alpha$-lactalbumin gene resulted in four different patterns (designated P1 to P4) with the following frequencies: $\mathrm{P} 1=65 \%, \mathrm{P} 2=23$, $\mathrm{P} 3=7 \%$ and $\mathrm{P} 4=5 \%$ (Figure 1). The $\alpha$-lactalbumin exon-I polymorphism recorded in this study was higher than that found by Barracosa (1996), who analyzed the same exon using the same methodology and primers but reported only two patterns in Portuguese Serrana goats (also C. hircus). High variability in milk yield found in Jamunapari goats reported by earlier workers (Acharya, 1982, Rout, 2004,) is supported by the results of our study and may be related to the high degree of $\alpha$-lactalbumin exon-I polymorphism found in our sample of this breed.

Several authors have pointed out that SSCP analysis is a reliable and reproducible technique for the detection of

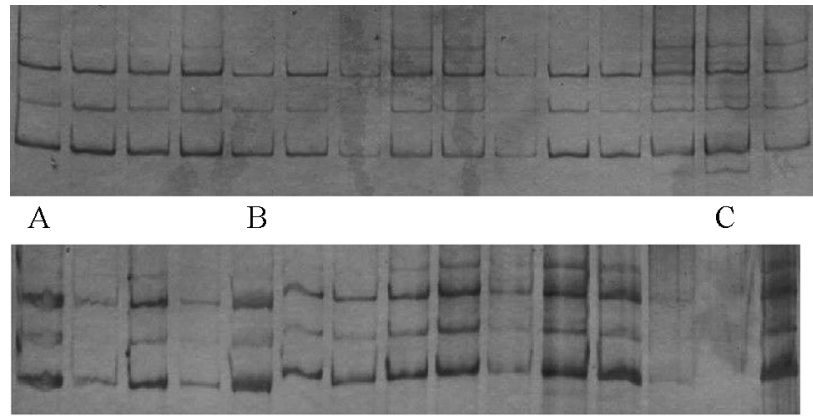

D)

Figure 1 - Jamunapari goat $\alpha$-lactalbumin polymerase chain reaction single-strand conformation polymorphism (PCR-SSCP) patterns on silver-stained native polyacrylamide gel.

structural gene polymorphism which is primarily due to point mutations (Neibergs et al., 1993; Sheffield et al., 1993; Barroso et al., 1999). In fact, Neibergs et al., (1993) have stated that SSCP analysis is the technique of choice when screening for point mutations and minor deletions within a given fragment, although it is necessary to optimize conditions for each specific case. Also, the nonradioactive PCR-SSCP method has several advantages in that it requires no specific equipment, is technically simpler and faster than other techniques, can be used in most laboratories and is not very expensive (Orita et al., 1989).

Our data show that PCR-SSCP is an appropriate tool for evaluating genetic variability, with this research representing the first application of molecular techniques to Jamnapari goats and the first step in the genetic characterization of this breed. The SSCP variants detected by us can be sequenced to produce new to single nucleotide polymorphism markers for association studies and markerassisted selection. The data generated by current studies may be useful for establishing possible associations between productive parameters and genetic variants and help in the process of decision making at the farmer' $s$ level for improvement and sustainable management of this goat breed.

\section{Acknowledgments}

The authors would like to thank the following people for help in the fieldwork and providing critical information: Dr J.S. Pal, Veterinary Officer, Bakewar, Etawah; Dr C.P. Tiwari, Livestock Extension Officer, Jamunapari Goat Breeding Centre, Chandai, Etawah; Dr V.P.S. Verma, Chief Veterinary Officer Etawah; Dr A.K. Singh, Director, Animal Husbandry, Government of Uttar Pradesh. We also thank The Director, National Bureau of Animal Genetic Resources (NBAGR) for providing facilities. The critical comments and suggestions of anonymous reviewers and editor are thankfully acknowledged. 


\section{References}

Acharya RM (1982) Sheep and goat breeds of India. FAO Animal Production and Health Paper 30, FAO, United Nations, Rome, pp 1-190.

Ahlawat SPS and Gupta SC (2004) Molecular genetic technologies for conservation of livestock. In: National Seminar on Biotechnology: A Tool for Sustainable Agricultural Production. GAU Gujarat, India.

Azevedo J, Mascarenhas M, Valentim R, Almeidal J, Silva S, Pires S and Teixeira M (1994) Preservação e Valorização dos Ovinos da Raça Churra da Terra Quente. Relatório Final do Projecto PAN I da Associação Nacional de Criadores de Ovinos Churra da Terra Quente, Torre de Moncorvo, Portugal.

Barracosa H (1996) Estudo de polimorfismos genéticos e da sua associação com capacidades de produção leiteira em caprinos de raça Algarvia e ovinos de raça Serra da Estrela. Dissertação de Mestrado, Universidade do Algarve, Faro.

Barroso A, Dunner S and Cañon J (1999) Technical note: Use of PCR-single strand conformation polymorphism analysis for detection of bovine $\beta$-casein variants A1, A2, A3 and B. J Anim Sci 77:2629-2632.

Devendra C (1985) Prolific breeds of goat. In: Land RB and Robinson DW (eds) Genetics of Reproduction in Sheep. Butterworths Publication, London, pp 69-80.
Neibergs H, Dietz A and Womack J (1993) Single-Strand Conformation Polymorphisms (SSCPs) detected in five bovine genes. Anim Genet 24:81-84.

Ng-Kwai-Hang K (1997) A review of the relationship between milk protein polymorphism and milk composition/milk production. IDF special issue 9702:22-37.

Orita M, Suzuki Y, Sekiya T and Hayashi K (1989) Rapid and sensitive detection of point mutation and DNA polymorphisms using polymerase chain reaction. Genomics 5:874879.

Rout PK, Mandal A, Singh MK, Roy R, Sharma N and Haenien GFW (2004) Jamunapari-A dairy goat breed of India. Dairy Goat Journal, May June, 2004, http://dairygoatjournal.com/ issues/05_06_04.html.

Sambrook J, Fritsch EF and Maniatis T (1989) Molecular Cloning: A Laboratory Manual $2^{\text {nd }}$ edition. Cold spring Harbour, Cold Spring Laboratory Press, NY.

Sambrook J and Russell DW (2001) Molecular Cloning: A Laboratory Manual $3^{\text {rd }}$ edition. Cold Spring Harbour, Cold Spring Laboratory Press, NY.

Sheffield V, Beck J, Kwitek A, Sandstrom D and Stone E (1993) The sensitivity of single-strand conformation polymorphism analysis for the detection of single base substitutions. Genomics 16:325-332.

Singh Harbans (1966) Domestic Animals. National Book Trust, India, pp 51.

Vilotte J, Soulier S, Printz C and Mercier J (1991) Sequence of the goat $\alpha$-lactalbumin-encoding gene: Comparison with its bovine gene and evidence of related sequences in the goat genome. Gene 98:271-276.

Associate Editor: Pedro Franklin Barbosa 